\title{
FEEding DURing red cell transfusion (FEEDUR RCT): a multi-arm randomised controlled trial
}

Tim Schindler ${ }^{1,2^{*}}$, Kee Thai Yeo $^{3}$, Srinivas Bolisetty ${ }^{1,2}$, Joanna Michalowski ${ }^{1}$, Alvin Hock Kuan $\operatorname{Tan}^{4}$ and Kei Lui ${ }^{1,2}$

\begin{abstract}
Background: Necrotising Enterocolitis (NEC) is a devastating neonatal disease. A temporal association between red cell transfusion and NEC has been recognized and there have been concerns about the effects of feeding during transfusion. We aimed to assess the effect of different enteral feeding regimens on splanchnic oxygenation in preterm infants receiving red cell transfusions.
\end{abstract}

Methods: This was an open, multi-arm, parallel-group, randomised controlled trial conducted in a single centre in Australia. We compared three different enteral feeding regimes during a single red cell transfusion in preterm infants $<35$ weeks gestational age at birth. Infants were randomised to either: (1) Withholding enteral feeds for $12 \mathrm{~h}$ from the start of transfusion or; (2) Continuing enteral feeds or; (3) Restriction of enteral feed volume to $120 \mathrm{ml} / \mathrm{kg} /$ day (maximum $20 \mathrm{kcal} / 30 \mathrm{ml}$ ) for $12 \mathrm{~h}$. The primary outcome was mean splanchnic-cerebral oxygenation ratio (SCOR) and mean splanchnic fractional oxygen extraction (FOE) before (1 h prior), during (1 h into transfusion) and after (end of transfusion; 12 and $24 \mathrm{~h}$ post) transfusion.

Results: There were 60 transfusion episodes (20 transfusion episodes in each group) included in the analysis. 41 infants with a median gestational age at birth of 27 weeks (range 23-32 weeks) were enrolled. The median postnatal age was 43 days (range 19-94 days) and the median pre-transfusion haematocrit was 0.27 (range $0.22-$ 0.32). All three groups were similar at baseline. There were no differences in mean SCOR and mean splanchnic FOE at any of the pre-specified time points. There were also no differences in clinical outcomes. There were no episodes of NEC in any infant. Across all groups the mean SCOR increased from the start to the end of each transfusion (0.97 [CI95\% 0.96-0.98] vs 1.00 [C195\% 0.99-1.01]; $p=0.04$ ) and the mean FOE decreased from the start to the end of each transfusion (0.22 [Cl95\% 0.21-0.23] vs 0.17 [Cl95\% 0.16-0.18]; $p<0.001$ ).

Conclusions: There were no differences in splanchnic oxygenation when enteral feeds were either withheld, continued or restricted during a transfusion. However, the successful conduct of this study supports the feasibility of a large trial powered to assess clinical outcomes.

Trial registration: ANZCTR, ACTRN12616000160437. Registered 10 February 2016, https://www.anzctr.org.au/Trial/ Registration/TrialReview.aspx?id=370069

Keywords: Preterm infant, Clinical trial, Near-infrared spectroscopy, Necrotizing enterocolitis

\footnotetext{
* Correspondence: tim.schindler@health.nsw.gov.au

'Department of Newborn Care, Royal Hospital for Women, Sydney, Australia

${ }^{2}$ School of Women's and Children's Health, University of New South Wales, Sydney, Australia

Full list of author information is available at the end of the article
}

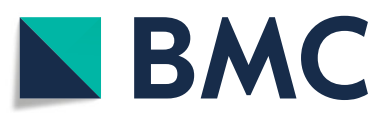

(c) The Author(s). 2020 Open Access This article is licensed under a Creative Commons Attribution 4.0 International License, which permits use, sharing, adaptation, distribution and reproduction in any medium or format, as long as you give appropriate credit to the original author(s) and the source, provide a link to the Creative Commons licence, and indicate if changes were made. The images or other third party material in this article are included in the article's Creative Commons licence, unless indicated otherwise in a credit line to the material. If material is not included in the article's Creative Commons licence and your intended use is not permitted by statutory regulation or exceeds the permitted use, you will need to obtain permission directly from the copyright holder. To view a copy of this licence, visit http://creativecommons.org/licenses/by/4.0/ The Creative Commons Public Domain Dedication waiver (http://creativecommons.org/publicdomain/zero/1.0/) applies to the data made available in this article, unless otherwise stated in a credit line to the data. 


\section{Background}

Necrotising enterocolitis (NEC) is a serious inflammatory gut disease that affects 1 in 20 very preterm infants [1]. About 1 in 3 infants with NEC die or need surgery and many survivors have long-term health problems like poor growth and developmental delay [2]. The association between red blood cell (RBC) transfusions and the development of NEC in preterm infants has been increasingly recognised $[3,4]$. This association between RBC transfusion and NEC may be coincidental as most preterm infants will receive transfusions within the first 4 weeks of life, which is the same time frame for the development of NEC. Further, it has been proposed that severe anaemia rather than the transfusion may be the precipitant event [5].

Mechanisms related to the development of transfusionassociated NEC (TANEC) are unknown. Several hypotheses have been proposed including the prolonged storage of blood, increased viscosity of blood, hypoperfusionreperfusion injury and enteral feeding [5-8]. The effect of enteral feeding during RBC transfusion on splanchnic perfusion and oxygenation has not been fully elucidated. Theoretically, RBC transfusion may eliminate the usual increase in splanchnic blood flow that follows feeding, placing infants at risk of hypoperfusion. Withholding feeds may prevent this and reduce the risk of NEC [9]. Due to the association between NEC and feeding practices, there have been concerns about the effects of feeding during $\mathrm{RBC}$ transfusion [10-12]. As a result, there is a wide variety of feeding practices during $\mathrm{RBC}$ transfusion of preterm infants including withholding of feeds to reduce the risk of NEC.

Near-infrared spectroscopy (NIRS) allows for the noninvasive real-time measurement of tissue oxygenation [13]. Observational studies have suggested that feeding during RBC transfusion may alter splanchnic tissue oxygenation and predispose infants to the development of TANEC [9]. In this pilot study, we aimed to systematically study the effect of three different enteral feeding regimens on splanchnic oxygenation in preterm infants receiving $\mathrm{RBC}$ transfusions. We hypothesised that enteral feeding during RBC transfusions would have no effect on splanchnic oxygenation.

\section{Methods}

\section{Trial design}

We conducted a single-centre, open, parallel-group, randomised control trial, investigating three different enteral feeding regimes during a single RBC transfusion.

\section{Participants}

Preterm infants admitted to the Neonatal Intensive Care Unit at the Royal Hospital for Women were enrolled between July 2016 and November 2017. Eligibility criteria for study inclusion were: Preterm infants born at $<35$ weeks' gestation; Receiving RBC transfusion for anaemia; Enteral feeding of at least $120 \mathrm{ml} / \mathrm{kg} /$ day. Exclusion criteria were: < 28 weeks' corrected gestation at time of $\mathrm{RBC}$ transfusion; Growth restriction (birth weight $<3$ rd centile); Major congenital anomalies (including severe cardiac or cerebral disease, any malformation or disease of the gastrointestinal tract); Diagnosis of necrotising enterocolitis, spontaneous intestinal perforation or history of abdominal surgery; Need for vasopressor therapy at study entry point; Cutaneous disease not allowing for placement of NIRS sensor.

\section{Interventions}

Infants were randomised to either: (1) Withholding enteral feeds for $12 \mathrm{~h}$ from the start of the transfusion or; (2) Continuing enteral feeds or; (3) Restriction of enteral feed volume to $120 \mathrm{ml} / \mathrm{kg} /$ day (maximum calorie concentration $20 \mathrm{kcal} / 30 \mathrm{ml}$ ) for $12 \mathrm{~h}$ from the start of the transfusion. Infants who did not receive enteral feeds during the transfusion were given intravenous fluids until enteral feeds were restarted. Infants who received enteral feeds during the transfusion continued according to the feeding regimen prior to the transfusion, which may have been continuous feeds or bolus feeds every $1-$ $3 \mathrm{~h}$. All transfusions were given over $4 \mathrm{~h}$ as per local policy. Each transfusion episode was treated as a separate event. Infants were assessed for eligibility and randomized with each transfusion.

\section{NIRS measurements}

NIRS readings were obtained using the Nonin SenSmart Model X-100 Universal Oximetry System (NONIN Inc., Minnesota, USA), which was calibrated to continuously record. Neonatal sensors were secured with tape to the lateral aspect of the forehead to measure cerebral oxygenation and below the umbilicus to measure splanchnic oxygenation. Sensors were placed $1 \mathrm{~h}$ prior to the start of the transfusion and removed $24 \mathrm{~h}$ later. Vital signs including oxygen saturations $(\mathrm{SaO} 2)$ were recorded at the same time as NIRS measurements.

NIRS data for extraction were identified by predetermined time stamps. NIRS data for each measurement contained approximately 150 data points (one data point every $4 \mathrm{~s}$ over $10 \mathrm{~min}$ ). Artefacts as a result of infant movement or incorrect sensor position were noted and eliminated at the stage of data analysis. Splanchnic cerebral oxygenation ratio (SCOR), cerebral and splanchnic fractional oxygen extraction (cerebral FOE and splanchnic FOE) were determined from the average raw data of regional cerebral saturation $\left(\mathrm{rSO}_{2} \mathrm{C}\right)$ and regional splanchnic saturation $\left(\mathrm{rSO}_{2} \mathrm{~S}\right)$, measured by NIRS. The following calculations were applied [14]:. 


$$
\begin{aligned}
& \mathrm{SCOR}=\frac{\mathrm{rSO}_{2} \mathrm{~S}}{\mathrm{rSO}_{2} \mathrm{C}} \\
& \text { Cerebral FOE }=\frac{\mathrm{SaO}_{2}-\mathrm{rSO}_{2} \mathrm{C}}{\mathrm{SaO}_{2}} \\
& \text { Splanchnic FOE }=\frac{\mathrm{SaO}_{2}-\mathrm{rSO}_{2} \mathrm{C}}{\mathrm{SaO}_{2}}
\end{aligned}
$$

\section{Outcomes \\ Primary outcomes}

1. Mean SCOR measurements over 4 time periods: pre-transfusion ( $1 \mathrm{~h}$ prior to transfusion), during transfusion ( $1 \mathrm{~h}$ into transfusion), end of transfusion, post-transfusion (12 and $24 \mathrm{~h}$ after end of transfusion).

2. Mean splanchnic FOE measurements.

\section{Secondary outcomes (assessed by review of medical records)}

1. Time to return to full feeds, defined as the number of hours after the $12 \mathrm{~h}$ feeding regimen until the infant is receiving the same feed volume as prior to the transfusion (at the discretion of the treating team).

2. Feed intolerance, defined by local guidelines at the time of the study (gastric aspirates $>30 \%$ of feed volume or vomiting).

3. Abdominal distension.

4. Adverse events including transfusion reactions, suspected or proven sepsis, TANEC (NEC within $48 \mathrm{~h}$ of transfusion).

5. Necrotising enterocolitis.

6. Late onset sepsis.

7. Mortality.

\section{Sample size}

Based on the only available published reference values in preterm neonates at the time of study design [15], we expected mean regional splanchnic oxygen saturations to be approximately $70 \%$ with a standard deviation of approximately $7 \%$. To detect a $10 \%$ change in mean splanchnic oxygenation, a sample size of at least 16 infants would be required to achieve $80 \%$ power at 0.05 level. We planned to recruit 20 infants per group.

\section{Randomisation and blinding}

Infants were randomised using a random allocation sequence in a 1:1:1 ratio. Allocations were concealed in opaque, sealed envelopes. A non-clinical investigator was responsible for the random allocation sequence.
Members of the clinical team enrolled and assigned participants.

This was an unblinded study, with feeding regimen assignments open to families, clinical staff and investigators.

\section{Statistical methods}

All analyses were performed by intention-to-treat and all 60 transfusion episodes were included in analyses of all outcomes. Given normal distribution of data, we used parametric statistics for our analyses. We used paired $t$ tests to determine any difference in pre-transfusion mean SCOR and post-transfusion SCOR within groups. Independent $\mathrm{t}$-tests were used to evaluate differences in mean SCOR between groups at all time points. We used repeated measures ANOVA to analyse changes in SCOR over the four pre-specified time points. Post-hoc tests, such as Tukey's, were performed to further analyse significant results. When assessing differences between the three groups, we stated a priori that we expected that the time points where we expected to see significant differences were at the end of the transfusion $(4 \mathrm{~h}$ poststarting) and at the point the feeding regimen returned to normal ( $12 \mathrm{~h}$ post-starting). We expected the observed differences to be most likely between infants in the full feeds group and no feeds group. The statistical analysis accommodated for infants who were enrolled in the study more than once for discrete transfusion episodes and for any infants with missing data points. Clinical outcome data were analysed using a combination of chi-squared, ANOVA and Kruskall-Wallis tests as appropriate.

\section{Results}

Figure 1 shows the Consolidated Standards of Reporting Trials diagram for recruitment. There were 60 transfusion episodes (20 transfusion episodes in each group) included in the analysis. One infant allocated to restricted feeds was not restricted to a maximum calorie concentration of $20 \mathrm{kcal} / 30 \mathrm{~mL}$. One infant allocated to continuing feeds discontinued feeds due to abdominal distension during the observation period.

Table 1 shows the baseline demographic and clinical characteristics for each group. 41 infants with a median gestational age at birth of 27 weeks (range 23-32 weeks) were enrolled. All three groups had similar perinatal characteristics. Infants allocated to restricted feeds had a lower corrected gestational age at the time of transfusion.

There were no differences in mean SCOR and mean splanchnic FOE at any of the pre-specified time points (see Fig. 2; Table 2). Before transfusion, there were no differences between groups (mean SCOR No feeds $0.97 \pm 0.10$ vs Full feeds $-0.97 \pm 0.09$ vs Restricted feeds 


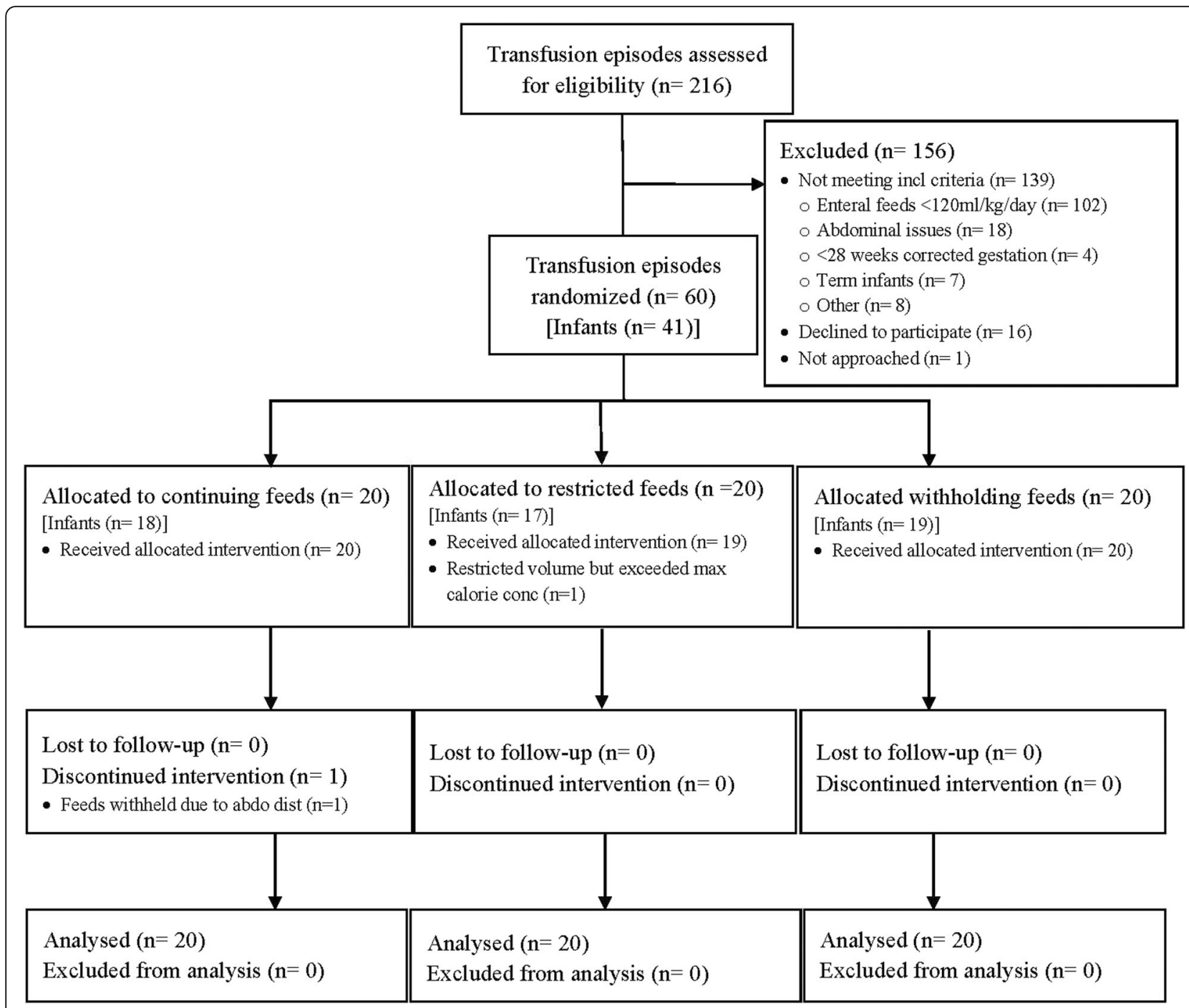

Fig. 1 Trial flowchart. Consolidated Standards of Reporting Trials diagram for participant flow through the study

$0.98 \pm 0.07[p=0.72]$; mean FOE No feeds $-0.25 \pm 0.07$ vs Full feeds $-0.22 \pm 0.07$ vs Restricted feeds $0.20 \pm 0.07$ $[p=0.72])$. Similarly, there were no differences between groups at the end of the transfusion (mean SCOR No feeds $-0.99 \pm 0.09$ vs Full feeds $-0.98 \pm 0.07$ vs Restricted feeds $1.02 \pm 0.07$ [ $p=0.20]$; mean FOE No feeds - $0.19 \pm 0.06$ vs Full feeds $-0.18 \pm 0.06$ vs Restricted feeds $0.16 \pm 0.05[p=0.16])$ or $12 \mathrm{~h}$ after starting the transfusion when the feeding regime returned to normal (mean SCOR No feeds - $0.99 \pm 0.09$ vs Full feeds $0.99 \pm 0.12$ vs Restricted feeds $0.99 \pm 0.08[p=1.0]$; mean FOE No feeds $-0.21 \pm 0.07$ vs Full feeds $-0.19 \pm 0.09$ vs Restricted feeds $0.20 \pm 0.07$ [ $p=0.83]$ ).

With respect to clinical outcomes, there were no differences in: Time to return to full feeds; Abdominal distension; Adverse events; TANEC (see Table 3). One infant in the restricted feeds arm was treated for suspected NEC, which was not subsequently proven. There were no episodes of proven NEC or mortality in any infant involved in the study. Feed intolerance (predominantly due to gastric aspirates $>30 \%$ of feed volume) occurred more frequently in infants in the full feeds arm (No feeds 0\% vs Full feeds 25\% vs Restricted feeds 5\%; $p=0.02$ ).

Across all groups, regional splanchnic saturations increased from the start to end of each transfusion (75 \pm 6.6 vs $79 \pm 5.2$; MD 4.3 [95\% CI 2.5-6.0]). The mean SCOR increased from the start to end of each transfusion $(0.97 \pm 0.09$ vs $1.00 \pm 0.08$; MD 0.03 [95\% CI $0.01-$ 0.05]) and the mean FOE decreased from the start to end of each transfusion $(0.22 \pm 0.07$ vs $0.17 \pm 0.06$; MD -0.05 [95\% CI $-0.03--0.07])$.

\section{Discussion}

The results of this study demonstrated no differences in splanchnic oxygenation between feeding regimens either 
Table 1 Perinatal Characteristics

\begin{tabular}{|c|c|c|c|c|}
\hline & $\begin{array}{l}\text { Group } 1 \\
\text { No feeds } \\
n=19\end{array}$ & $\begin{array}{l}\text { Group } 2 \\
\text { Full feeds } \\
n=18\end{array}$ & $\begin{array}{l}\text { Group } 3 \\
\text { Restricted } n=17\end{array}$ & $p$-value \\
\hline Gestation at birth, mean \pm SD & $27.2 \pm 2.3$ & $26.4 \pm 2.1$ & $26.4 \pm 1.9$ & 0.38 \\
\hline Birth weight, mean $\pm S D$ & $1005 \pm 331$ & $847 \pm 218$ & $903 \pm 214$ & 0.16 \\
\hline Birth weight percentile, mean $\pm S D$ & $52 \pm 26$ & $49 \pm 29$ & $60 \pm 30$ & 0.46 \\
\hline Female sex, n (\%) & $10(50 \%)$ & $11(55 \%)$ & $11(55 \%)$ & 0.94 \\
\hline Singleton birth, $\mathrm{n}(\%)$ & $18(90 \%)$ & $17(85 \%)$ & $18(90 \%)$ & 0.85 \\
\hline Caesarean delivery, n (\%) & $14(70 \%)$ & $12(60 \%)$ & $10(50 \%)$ & 0.44 \\
\hline Maternal age, mean $\pm S D$ & $32 \pm 5$ & $32 \pm 5$ & $31 \pm 4$ & 0.88 \\
\hline Received antenatal corticosteroids, n (\%) & $20(100 \%)$ & $20(100 \%)$ & $20(100 \%)$ & $n / a$ \\
\hline Received antenatal magnesium, n (\%) & $11(55 \%)$ & $17(85 \%)$ & $13(65 \%)$ & 0.12 \\
\hline Grade III/IV intraventricular haemorrhage, n (\%) & 0 & 0 & $1(5 \%)$ & 0.36 \\
\hline Early onset sepsis, n (\%) & 0 & 0 & $1(5 \%)$ & 0.36 \\
\hline Postnatal age, mean \pm SD & $46 \pm 15$ & $48 \pm 18$ & $39 \pm 14$ & 0.14 \\
\hline Corrected gestational age, mean \pm SD & $34.4 \pm 4.0$ & $33.3 \pm 1.9$ & $31.8 \pm 2.3$ & $0.02^{*}$ \\
\hline Weight at time of study, mean \pm SD & $1702 \pm 640$ & $1512 \pm 524$ & $1440 \pm 500$ & 0.32 \\
\hline Haemoglobin pre-transfusion, mean \pm SD & $93 \pm 8$ & $92 \pm 8$ & $94 \pm 7$ & 0.66 \\
\hline Haematocrit pre-transfusion, mean \pm SD & $0.27 \pm 0.02$ & $0.27 \pm 0.03$ & $0.28 \pm 0.02$ & 0.72 \\
\hline Invasive ventilation at time of study, n (\%) & 0 & $3(15 \%)$ & $1(5 \%)$ & 0.15 \\
\hline Non-invasive respiratory support at time of study, n (\%) & $16(80 \%)$ & $14(70 \%)$ & $18(90 \%)$ & 0.29 \\
\hline Inspired oxygen at start of study period, mean \pm SD & $0.26 \pm 0.08$ & $0.28 \pm 0.10$ & $0.28 \pm 0.08$ & 0.65 \\
\hline Transfusion episodes $(n)^{* *}$ & 20 & 20 & 20 & \\
\hline
\end{tabular}

${ }^{*} p<0.05$

**Each transfusion episode treated as a discrete event

during transfusion or at any time point up to $24 \mathrm{~h}$ after transfusion. This was despite a consistent increase in regional splanchnic saturations from the start to the end of the transfusion in all three groups. These findings are in keeping with the hypothesis that there is an opportunity for ischaemic damage to the gastrointestinal system prior to a blood transfusion, which is followed by rapid reperfusion and an inflammatory cascade during and immediately after the transfusion [16]. However, this study found that changing the feeding regimen during transfusion had no effect on these physiological changes. This is not surprising given emerging evidence that severe anaemia, as opposed to the transfusion itself, may be the sentinel event that predisposes preterm infants to the development of NEC [5].

All studies that utilise NIRS technology are limited by a lack of standardisation with respect to processing and interpreting output data. In this study, we elected to average NIRS values over ten minutes at each prespecified time point but it is currently unclear whether this is optimal. Similarly, differences in variability or time below a threshold value may be a more appropriate representation of splanchnic blood flow compared with an average over time. NIRS data were extracted at five pragmatically selected time points, potentially missing differences in splanchnic oxygenation at other times during the observation period. In addition, we did not control for timing of feeding nor investigate response to feeding, which may have added value to the study. Splanchnic blood flow is normally increased in response to enteral feeds but RBC transfusion has been shown to suppresses this postprandial increase in preterm infants $[9,17,18]$. This postprandial increase is also absent in infants who develop NEC [19].

With regard to applicability in clinical practice, it is difficult to know how far we can extrapolate findings from physiological studies such as this. Splanchnic NIRS measurements have not been validated in the same way as cerebral NIRS measurements [20] and this fundamentally limits what we can infer clinically from these results. The study was limited by a low background incidence of NEC, with no eligible infant developing NEC during the study period or at any stage during hospitalisation. It is also important to acknowledge that we excluded infants less than 28 weeks' corrected gestation at the time of RBC transfusion due to individual clinician concerns. It is possible that differences in splanchnic oxygenation would have been apparent in these high 

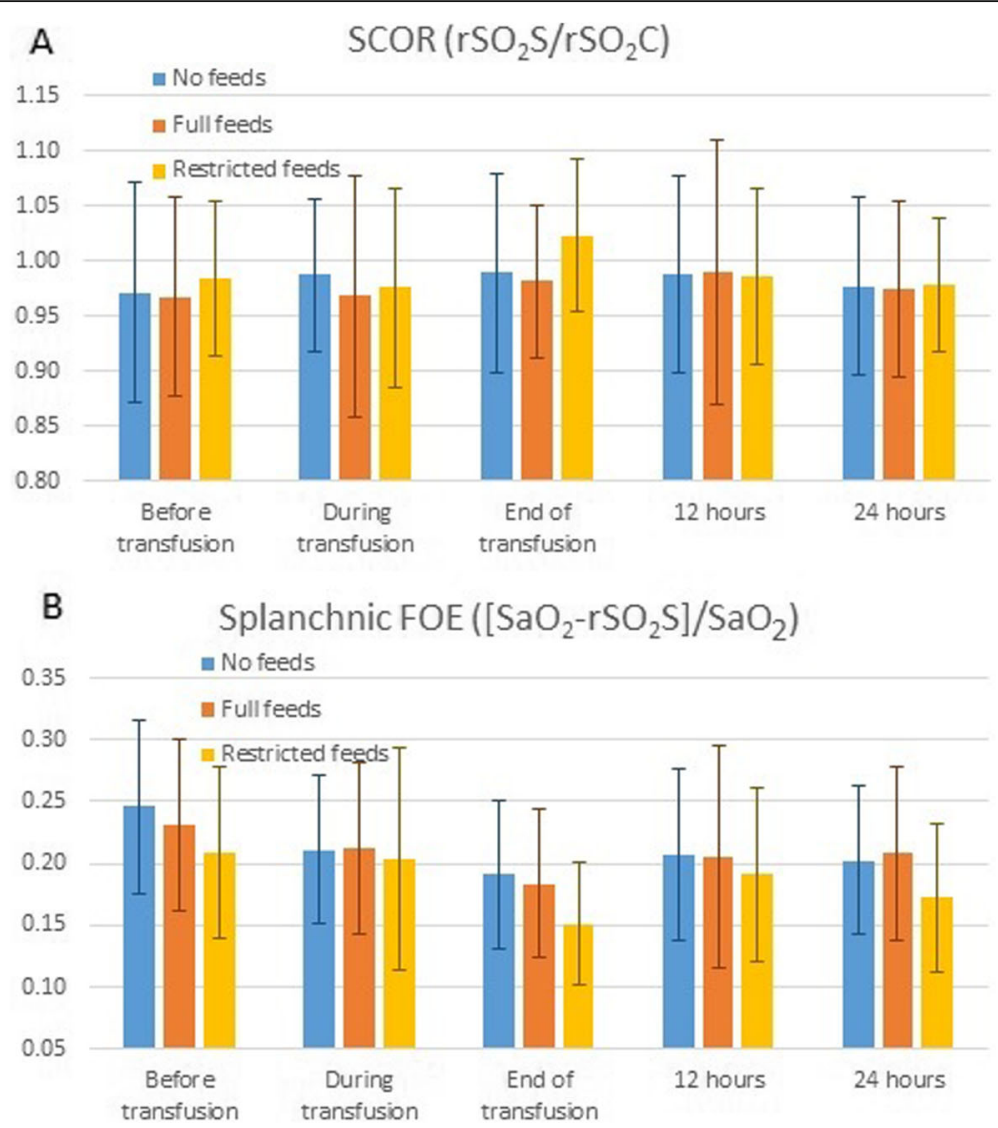

Fig. 2 Splanchnic oxygenation at pre-specified time points. a Mean (SD) splanchnic cerebral oxygenation ratio (SCOR; rSO2S/rSO2C); b Mean (SD) splanchnic fractional oxygen extraction (FOE; $[\mathrm{SaO} 2-\mathrm{rSO} 2 \mathrm{~S}] / \mathrm{SaO} 2)$

Table 2 NIRS values for splanchnic oxygenation at pre-specified time points

\begin{tabular}{|c|c|c|c|c|c|}
\hline \multicolumn{6}{|c|}{ Splanchnic saturations - mean (SD) } \\
\hline Time point & Before transfusion & During transfusion & End of transfusion & $12 \mathrm{~h}$ & $24 \mathrm{~h}$ \\
\hline No feeds & $74(7.2)$ & $76(5.3)$ & $78(5.2)$ & $77(6.0)$ & $77(5.4)$ \\
\hline Full feeds & $75(7.1)$ & $76(7.4)$ & $79(6.0)$ & $77(8.9)$ & $76(6.9)$ \\
\hline Restricted feeds & $76(5.6)$ & $76(7.4)$ & $80(4.3)$ & $77(5.9)$ & $77(4.9)$ \\
\hline$p$-value & 0.60 & 0.98 & 0.40 & 0.96 & 0.81 \\
\hline \multicolumn{6}{|l|}{ SCOR - mean (SD) } \\
\hline Time point & Before transfusion & During transfusion & End of transfusion & $12 \mathrm{~h}$ & $24 \mathrm{~h}$ \\
\hline No feeds & $0.97(0.10)$ & $0.99(0.07)$ & $0.99(0.09)$ & $0.99(0.09)$ & $0.98(0.09)$ \\
\hline Full feeds & $0.97(0.09)$ & $0.97(0.11)$ & $0.98(0.07)$ & $0.99(0.12)$ & $0.98(0.08)$ \\
\hline Restricted feeds & $0.98(0.07)$ & $0.98(0.09)$ & $1.02(0.07)$ & $0.99(0.08)$ & $0.98(0.06)$ \\
\hline$p$-value & 0.72 & 0.74 & 0.20 & 1.0 & 0.99 \\
\hline \multicolumn{6}{|c|}{ Mesenteric FOE - mean (SD) } \\
\hline Time point & Before transfusion & During transfusion & End of transfusion & $12 \mathrm{~h}$ & $24 \mathrm{~h}$ \\
\hline No feeds & $0.25(0.07)$ & $0.21(0.06)$ & $0.19(0.06)$ & $0.21(0.07)$ & $0.20(0.06)$ \\
\hline Full feeds & $0.23(0.07)$ & $0.21(0.07)$ & $0.18(0.06)$ & $0.20(0.09)$ & $0.21(0.07)$ \\
\hline Restricted feeds & $0.21(0.07)$ & $0.20(0.09)$ & $0.15(0.05)$ & $0.19(0.07)$ & $0.17(0.06)$ \\
\hline$p$-value & 0.21 & 0.86 & 0.16 & 0.83 & 0.41 \\
\hline
\end{tabular}


Table 3 Clinical Outcomes. NEC - Necrotising Enterocolitis; TANEC - Transfusion-Associated NEC (NEC within $48 \mathrm{~h}$ of transfusion)

\begin{tabular}{|c|c|c|c|c|}
\hline & $\begin{array}{l}\text { Group } 1 \\
\text { No feeds }\end{array}$ & $\begin{array}{l}\text { Group } 2 \\
\text { Full feeds }\end{array}$ & $\begin{array}{l}\text { Group } 3 \\
\text { Restricted feeds }\end{array}$ & $p$-value \\
\hline Time to return to full feeds, hours \pm SD & $8 \pm 35$ & $13 \pm 46$ & $8 \pm 32$ & 0.88 \\
\hline Feed intolerance, n (\%) & 0 & $5(25 \%)$ & $1(5 \%)$ & $0.02^{*}$ \\
\hline Abdo distension, n (\%) & $1(5 \%)$ & $3(15 \%)$ & $2(10 \%)$ & 0.57 \\
\hline Adverse Events, n (\%) & 0 & 0 & $1(5 \%)^{* *}$ & 0.36 \\
\hline TANEC, $n$ & 0 & 0 & 0 & $\mathrm{n} / \mathrm{a}$ \\
\hline$N E C, n$ & 0 & 0 & 0 & $n / a^{* * *}$ \\
\hline Late onset sepsis, n & $11 / 19$ & $10 / 18$ & $7 / 17$ & $n / a^{* * *}$ \\
\hline Mortality, n & 0 & 0 & 0 & $\mathrm{n} / \mathrm{a}^{* * *}$ \\
\hline
\end{tabular}

${ }^{*} p<0.05$

**1 infant treated for suspected NEC (managed conservatively; not proven)

***not appropriate to compare rates of long term outcomes as feeding allocation was for one transfusion only

risk infants. Further, each transfusion episode was treated as a separate event. Although this choice suited the primary outcomes of the study, it places significant limitations on the interpretation of secondary clinical outcomes. We also acknowledge that there is significant clinical practice variation with respect to the timing of withholding feeds around transfusion in units that have adopted this strategy.

The absence of demonstrable differences in splanchnic oxygenation between feeding regimens highlights the importance of conducting a trial that investigates clinical outcomes. The effect of feeding a baby during a RBC transfusion and the subsequent development of NEC remains unclear [21]. A systematic review of "before-after" studies (7 studies; 7492 infants) showed a significant reduction in the risk of developing NEC within 48-72 $\mathrm{h}$ when feeds were withheld during a transfusion [22]. This should be interpreted with caution as historical comparisons are at high risk of ascertainment bias and regression to the mean [23]. Consequently, there are a variety of opinions about the optimal feeding regime for a baby having a $\mathrm{RBC}$ transfusion and there is consequently significant practice variation [24, 25]. The prevention of NEC has been identified as a top research priority in the care of preterm infants yet this question remains unanswered [26].

\section{Conclusions}

Inherently limited by a low background incidence of NEC, this study did not demonstrate any physiological differences in splanchnic oxygenation when enteral feeds were either withheld, continued or restricted during a transfusion. However, the successful conduct of this study suggests that a large trial powered to assess clinical outcomes is achievable to answer this important clinical question.

\section{Abbreviations}

FEEDUR RCT: FEEding DURing Red Cell Transfusion; NEC: Necrotising Enterocolitis; SCOR: Splanchnic-Cerebral Oxygenation Ratio; FOE: Fractional Oxygen Extraction; RBC: Red Blood Cell; TANEC: Transfusion-Associated Necrotising Enterocolitis; NIRS: Near-infrared Spectroscopy; $\mathrm{rSO}_{2} \mathrm{C}$ : Regional Cerebral Saturation; $\mathrm{rSO}_{2} \mathrm{~S}$ : Regional Splanchnic Saturation

\section{Acknowledgements}

The authors thank the babies and families who participated in the study. The authors also thank all the nursing staff of the Neonatal Intensive Care Unit at the Royal Hospital for Women who supported data collection and cared for the infants during the study. Special thanks to Andrew Martin and Kylie-Ann Mallitt for their statistical support.

\section{CONSORT guidelines}

This study adheres to the CONSORT (CONsolidated Standards of Reporting Trials) 2010 guideline.

\section{Authors' contributions}

TS and KTY conceived the study. TS, KTY, SB and KL designed the study. TS and JM coordinated the implementation of the study. TS, AHKT and JM were responsible for data acquisition. TS drafted the manuscript. All authors (TS, $\mathrm{KTY}, \mathrm{SB}, J \mathrm{M}, \mathrm{AHKT}$ and $\mathrm{KL}$ ) reviewed and revised the manuscript, providing important intellectual content, and approved the final version.

\section{Funding}

This study was supported by the Madison Capaldi Research Fund, a fundraising group that provides substantial research support to the Department of Newborn Care at the Royal Hospital for Women.

\section{Availability of data and materials}

All data generated or analysed during this study are included in this published article.

\section{Ethics approval and consent to participate}

This study was performed in accordance with the Declaration of Helsinki and approved by Human Research Ethics Committee of South Eastern Sydney Local Health District (Reference Number: 14/252). All parents or legal guardians provided written informed consent for infants to participate in the study.

Consent for publication

Not applicable.

\section{Competing interests}

The authors declare that they have no competing interests.

\section{Author details}

${ }^{1}$ Department of Newborn Care, Royal Hospital for Women, Sydney, Australia.

${ }^{2}$ School of Women's and Children's Health, University of New South Wales, 
Sydney, Australia. ${ }^{3}$ Department of Neonatology, KK Women's \& Children's Hospital, Singapore, Singapore. ${ }^{4}$ Department of Neonatal and Perinatal Medicine, Flinders Medical Centre, Adelaide, Australia.

Received: 17 March 2020 Accepted: 1 July 2020

Published online: 14 July 2020

\section{References}

1. Chow SSW, Creighton P, Chambers GM, Lui K. Report of the Australian and New Zealand neonatal network 2017. Sydney: ANZNN; 2019.

2. Hau EM, Meyer SC, Berger S, Goutaki M, Kordasz M, Kessler U. Gastrointestinal sequelae after surgery for necrotising enterocolitis: a systematic review and meta-analysis. Arch Dis Child Fetal Neonatal Ed. 2019; 104:F265-73.

3. Mohamed A, Shah PS. Transfusion associated necrotizing enterocolitis: a meta-analysis of observational data. Pediatrics. 2012;129:529-40.

4. McGrady GA, Rettig PJ, Istre GR, Jason JM, Holman RC, Evatt BL. An outbreak of necrotizing enterocolitis. Association with transfusions of packed red blood cells. Am J Epidemiol. 1987;126:1165-72.

5. Patel RM, Knezevic A, Shenvi N, Hinkes M, Keene S, Roback JD, et al. Association of red Blood Cell Transfusion, Anemia, and necrotizing Enterocolitis in very low-birth-weight infants. JAMA. 2016;315:889-97.

6. Reynolds JD, Ahearn GS, Angelo M, Zhang J, Cobb F, Stamler JS. Snitrosohemoglobin deficiency: a mechanism for loss of physiological activity in banked blood. Proc Natl Acad Sci U S A. 2007;104:17058-62.

7. Kristiansson M, Soop M, Saraste L, Sundqvist KG. Cytokines in stored red blood cell concentrates: promoters of systemic inflammation and simulators of acute transfusion reactions? Acta Anaesthesiol Scand. 1996:40:496-501.

8. Nelle M, Höcker C, Zilow EP, Linderkamp O. Effects of red cell transfusion on cardiac output and blood flow velocities in cerebral and gastrointestinal arteries in premature infants. Arch Dis Child Fetal Neonatal Ed. 1994;71:F45-8.

9. Marin $\mathrm{T}$, Josephson CD, Kosmetatos N, Higgins M, Moore JE. Feeding preterm infants during red blood cell transfusion is associated with a decline in postprandial mesenteric oxygenation. J Pediatr. 2014;165:464-71.

10. Oddie SJ, Young L, McGuire W. Slow advancement of enteral feed volumes to prevent necrotising enterocolitis in very low birth weight infants. Cochrane Database Syst Rev. 2017:CD001241.

11. Kirtsman M, Yoon EW, Ojah C, Cieslak Z, Lee SK, Shah PS. Nil-per-os days and necrotizing enterocolitis in extremely preterm infants. Am J Perinatol. 2015;32:785-94.

12. Keir AK, Wilkinson D. Question 1 * do feeding practices during transfusion influence the risk of developing necrotising enterocolitis in preterm infants? Arch Dis Child. 2013:98:386-8

13. Fortune PM, Wagstaff M, Petros AJ. Cerebro-splanchnic oxygenation ratio (CSOR) using near infrared spectroscopy may be able to predict splanchnic ischaemia in neonates. Intensive Care Med. 2001;27:1401-7.

14. Van Bel F, Lemmers P, Naulaers G. Monitoring neonatal regional cerebral oxygen saturation in clinical practice: value and pitfalls. Neonatology. 2008; 94:237-44.

15. Hyttel-Sorensen S, Pellicer A, Alderliesten T, Austin T, van Bel F, Benders M, et al. Cerebral near infrared spectroscopy oximetry in extremely preterm infants: phase II randomised clinical trial. BMJ. 2015;350:97635.

16. MohanKumar K, Namachivayam K, Song T, Jake Cha B, Slate A, Hendrickson $\mathrm{JE}$, et al. A murine neonatal model of necrotizing enterocolitis caused by anemia and red blood cell transfusions. Nat Commun. 2019;10:3494.

17. Blau J, Calo JM, Dozor D, Sutton M, Alpan G, La Gamma EF. Transfusionrelated acute gut injury: necrotizing enterocolitis in very low birth weight neonates after packed red blood cell transfusion. J Pediatr. 2011:158:403-9.

18. Krimmel GA, Baker R, Yanowitz TD. Blood transfusion alters the superior mesenteric artery blood flow velocity response to feeding in premature infants. Am J Perinatol. 2009;26:99-105.

19. Kempley ST, Gamsu HR. Superior mesenteric artery blood flow velocity in necrotising enterocolitis. Arch Dis Child. 1992;67:793-6.

20. Seagar $\mathrm{E}$, Longley C, Aladangady N, Banerjee J. Measurement of gut oxygenation in the neonatal population using near-infrared spectroscopy: a clinical tool? Arch Dis Child Fetal Neonatal Ed. 2020;105:76-86.

21. Yeo KT, Kong JY, Sasi A, Tan K, Lai N, Schindler T. Stopping enteral feeds for prevention of transfusion-associated necrotising enterocolitis in preterm infants. Cochrane Database Syst Rev. 2019:CD012888.
22. Jasani B, Rao S, Patole S. Withholding feeds and transfusion-associated necrotizing enterocolitis in preterm infants: a systematic review. Adv Nutr. 2017:8:764-9.

23. National Blood Authority (NBA). Patient Blood Management Guidelines: Module 6 - Neonatal and Paediatrics. Canberra: NBA; 2016.

24. Parige R, Turner C, Sundaram S, Power S. Enteral feeding during packed red blood cell transfusion in English neonatal units. Arch Dis Child Fetal Neonatal Ed. 2013;99:F173.

25. Calo JM, Blau J, La Gamma EF. A survey of attending neonatologists on transfusion related acute gut injury (tragi): the association between necrotizing enterocolitis (nec) and prbc transfusion. Pediatric Academic Societies 2009:E-PAS

26. Duley L, Uhm S, Oliver S, Preterm Birth Priority Setting Partnership Steering Group. Top 15 UK research priorities for preterm birth. Lancet. 2014;383: $2041-2$

\section{Publisher's Note}

Springer Nature remains neutral with regard to jurisdictional claims in published maps and institutional affiliations.

Ready to submit your research? Choose BMC and benefit from:

- fast, convenient online submission

- thorough peer review by experienced researchers in your field

- rapid publication on acceptance

- support for research data, including large and complex data types

- gold Open Access which fosters wider collaboration and increased citations

- maximum visibility for your research: over $100 \mathrm{M}$ website views per year

At BMC, research is always in progress.

Learn more biomedcentral.com/submissions 